\title{
The Research on the Relationship of Manager Characteristics and
}

\author{
Firm Earnings Management \\ Jianjun Zhang ${ }^{*}$, Yang Xu \\ School of Economics and Management, Hubei University of Science and Technology, P.R. \\ China \\ *Corresponding author: Jianjun Zhang, Master 's Degree, zjj7708@163.com
}

\begin{abstract}
With the prosperity of economy, the earnings management of listed companies are paid attention by people. The research of the listed company managers characteristics and what earnings management way have very important significance.Firstly in this paper, with the Shanghai stock exchange in 2012 data of a-share listed companies as samples, use SPSS to analyze it, finally it is concluded that some of the characteristics of managers is correlation with earnings management. According to the empirical conclusions, I put forward some suggestions to improve earnings management of listed companies.
\end{abstract}

Keywords: management characteristics;earnings management;listed company

\section{Introduction}

Many factors affect earnings management, socio-economic and cultural factors such as the accounting profession, but these are external factors, and is characterized by internal managers of listed companies one of the most important factors is the root of a listed company earnings management.

American Accounting scientist Scott believes that earnings management is an act within generally accepted accounting principles permitted range, through policy choices to achieve their own interests to maximize the operator or the enterprise market to maximize the value. US accounting scholar Catherine snow Perot view is that earnings management is in fact of business managers with a head to be controlled external financial reporting, in order to gain some personal benefit "Disclosure Management."

Earnings management research in China is relatively foreign to late, for now, the research on earnings management is not very comprehensive, most research accruals for earnings management. Lu Jianqiao found that the use of working capital projects, especially projects accounts payable, inventory item listed company as a means of loss of earnings management ${ }^{1}$.This future earnings management has some significance. Subsequently, Lizeng Quan found that listed companies use assets impairment earnings management to increase or decrease revenues ${ }^{2}$. When companies face placement, temporary deficits in motivation and 
Akira crisis, increase asset impairment policy future earnings will be smoothed with a profit motive, motivation and loss of motivation to change a company to choose. This is to show the different policies of the Public Company Accounting Earnings Management Motivation.

\section{Executives characteristics of earnings management analysis and correlation assumptions}

H1: male executives, the greater the probability of earnings management.

$\mathrm{H} 2$ : the greater the executives of age, the smaller the motivation of earnings management.

H3: The more educated executive level, the smaller the probability of earnings management.

$\mathrm{H} 4$ : The longer the tenure of executives, the smaller the likelihood of earnings management

\section{Executives feature selection on earnings management Empirical Analysis}

\subsection{Sample Selection and Data Sources}

This paper selected the 2012 Shanghai Stock Exchange A-share listed companies as samples, using spss17.0 sample data for analysis. (1) Taking into account the importance of research on education managers, the paper screening sample data excludes managers educated unknown samples. (2) the exclusion of operations and financial condition of abnormal ST, * ST business samples, the performance of such enterprises in the period when a more substantial fluctuations may lead managers on Business Performance features no obvious regularity. (3) in order to ensure the stability of the data, excluding real estate and financial companies subject to a large range of national policy of the enterprise.

As used herein, the data from China's economic and financial databases and major financial report, the ultimate controlling different backgrounds, to distinguish non-state-owned listed companies and listed companies, the same time with various leading financial websites as supplementary data. Each industry with 10 percent selection, ultimately, the total number of samples 478, 208 state-owned listed companies, non-state-owned listed companies 270.

\subsection{Variable design and description}

Study variables paper includes earnings management variables, managers characteristic variables and control variables in three parts. According to the description part of the definition of the concept before, this article selected explanatory variables (earnings management) for the ROE; explanatory variables (manager characteristic index) include the manager's age, gender, education, tenure,. In order to control other factors, a comprehensive research of many scholars, this paper selects the net assets of revenue, operating income and the proportion of the largest shareholder as control variables in this study. 


\subsubsection{Explained variable}

Corporate performance is the dependent variable of this article. On the measure of corporate performance indicators selected, different scholars choose different targets. Reference herein Li Yan, Zhou Yixiang ROE in the study used to measure corporate earnings ${ }^{3}$. ROE is a company's profit after tax divided by the percentage rate of net assets obtained, the index reflects the level of shareholders' equity income, the higher the index value, the higher income investment ${ }^{4}$. ROE can be a measure of corporate shareholders invested capital utilization efficiency. Hence the ROE to measure earnings management is more reliable ${ }^{5}$.

\subsubsection{Explanatory variables}

(1) Managers of age. Birth year income managers by age indicates.

(2) Sex managers. A value of 1 male, female to 0 , with gend expressed.

(3) manager qualifications. Financial database using the division of education, and are based on the assignment manager education, including secondary and secondary value of 1 or less, college value of 2, a value of 3 undergraduate, graduate value of 4, Ph.D. a value of 5, represented by degre.

(4) The term of office manager. Managers term refers to assuming his current position in time, in the calculation of the term, some less than six months are not counted, more than six months less than one year, part as one year, with the time represented.

\subsubsection{The control variable}

This paper selects the net asset income, operating income factors, net profit of three may have an impact on earnings management as a control variable.

(1) Net assets income. Learn from the experience of scholars, net assets income will affect earnings management, this paper selected net assets income as one control variable, represented by pro.

(2) operating income. How much revenue directly reflects the company's good or bad, and earnings management has a direct contact, thus we choose revenue as one of the control variables, tak expressed.

(3) the largest shareholder stake. The major shareholder of the enterprise business decision-making often plays an important role, thereby affecting corporate earnings management, thus we choose the ratio of the largest shareholder as one control variable is represented by top 1 .

\subsection{Executives characteristic descriptive statistics}

Spss17.0 use statistical analysis software in accordance with the total sample, a sample of state-owned listed companies, non-state-owned enterprises listed on the main variables 
involved in the sample were descriptive statistical analysis, the results as shown in Table 1.2.3.

Table 1 Descriptive statistics for all sample variables

\begin{tabular}{|l|l|l|l|l|l|l|}
\hline variable & $\mathrm{N}$ & Mean & median & Standard deviation & Minimum value & Maximum value \\
\hline age & 478 & 50.0816 & 50.0000 & 7.1849 & 29.0000 & 72.0000 \\
\hline gend & 478 & 0.9351 & 1.0000 & 0.2465 & 0.0000 & 1.0000 \\
\hline degre & 478 & 3.4184 & 4.0000 & 0.8859 & 1.0000 & 5.0000 \\
\hline time & 478 & 4.9498 & 5.0000 & 2.5381 & 1.0000 & 12.0000 \\
\hline
\end{tabular}

Table 2 Descriptive statistics of the variables of state-owned listed companies

\begin{tabular}{|l|l|l|l|l|l|l|}
\hline variable & $\mathrm{N}$ & Mean & median & Standard deviation & Minimum value & Maximum value \\
\hline age & 208 & 53.1731 & 53.0000 & 6.2104 & 37.0000 & 72.0000 \\
\hline gend & 208 & 0.9663 & 1.0000 & 0.1808 & 0.0000 & 1.0000 \\
\hline degre & 208 & 3.5433 & 4.0000 & 0.8614 & 1.0000 & 5.0000 \\
\hline time & 208 & 5.6250 & 6.0000 & 2.8342 & 1.0000 & 12.0000 \\
\hline pro & 208 & 22.3289 & 22.0277 & 1.2141 & 19.8277 & 26.4828 \\
\hline tak & 208 & 0.5230 & 0.5365 & 0.1853 & 0.0505 & 0.9458 \\
\hline topl & 208 & 0.3600 & 34.9400 & 14.1195 & 0.0750 & 0.8251 \\
\hline
\end{tabular}

Table 3 Descriptive statistics of non-state-owned enterprises listed variables

\begin{tabular}{|l|l|l|l|l|l|l|}
\hline variable & $\mathrm{N}$ & Mean & median & Standard deviation & Minimum value & Maximum value \\
\hline roa & 270 & 0.0564 & 0.0516 & 0.0497 & -0.1077 & 0.3132 \\
\hline age & 270 & 47.7000 & 48.0000 & 6.9840 & 29.0000 & 72.0000 \\
\hline gend & 270 & 0.9111 & 1.0000 & 0.2851 & 0.0000 & 1.0000 \\
\hline degre & 270 & 3.3222 & 3.0000 & 0.8939 & 1.0000 & 5.0000 \\
\hline time & 270 & 4.4296 & 5.0000 & 21.4890 & 1.0000 & 11.0000 \\
\hline pro & 270 & 21.4120 & 21.3305 & 0.8048 & 19.0778 & 23.9300 \\
\hline tak & 270 & 0.3277 & 0.3068 & 0.1945 & 0.0260 & 0.9489 \\
\hline topl & 270 & 0.3760 & 36.6250 & 15.1726 & 0.0923 & 0.8523 \\
\hline
\end{tabular}

Seen from Table 1.2.3, the entire study sample totaled 478, including 208 state-owned listed companies, non-state-owned listed companies 270.

Performance aspects of business, the average total return on assets of all enterprises in the sample was 0.0474 , the average total return on assets of state-owned listed companies was 0.0357, less than the non-state-owned listed companies 0.0564 , the maximum and minimum gap between the three groups of samples are $40 \%$ above, indicating that there is a big difference in the profitability of enterprises. 
Terms of age, the average age of the entire sample enterprise managers to 50.0816, a standard deviation of 7.1849. Listed state-owned enterprise managers average age of 53.1731, age distribution is 37-72, with a median of 53 and a standard deviation of 6.2104; non-listed state-owned enterprise managers an average age of 47.7, the age distribution of 29-72, the median 48 years, standard deviation of 6.9840. It can be seen listed state-owned enterprise managers were significantly older than non-listed state-owned enterprise managers, and the three groups are larger sample variance, age distribution more dispersed.

Whether it is state-owned listed companies and non-listed state-owned enterprises, which account for the vast majority of male managers, three groups of male managers in the sample accounted 0.9351,0.9663 and 0.9111, respectively, state-owned listed companies is slightly larger than the proportion of male managers non-state-owned listed companies.

Academic qualifications, education manager for the entire sample of 3.4184, with a median of 4 , the standard deviation of 0.8859; state-owned enterprise managers listed education as 3.5433, with a median of 4 , the standard deviation of 0.8614 ; non-listed state-owned enterprise managers Degree to 3.3222, with a median of 3, the standard deviation of 0.8939 . In accordance with article before assignment criteria, it can be seen from the above figures, whether state-owned and non-state-owned listed companies, managers are in undergraduate education - between Master degree is relatively high, slightly higher than the listed state-owned enterprise managers educated non-listed state-owned business, which may be more emphasis on their own quality manager ascension, and the emphasis on education phenomenon is more evident in the listed state-owned enterprise managers.

The term of all the sample mean of 4.9498 managers, managers of state-owned enterprises listed on term mean of 5.6250 for a term of 1 to 12 distribution, the standard deviation of 2.8342; non-listed state-owned enterprise managers term mean of 4.4296, a term distribution 1- 11, a standard deviation of 2.1489. As can be seen, the listed state-owned enterprise managers term mean is greater than the non-state listed companies, compared to non-state-owned enterprises listed on term distribution is more dispersed.

Aspect ratio of the largest shareholder, the total sample, listed state-owned enterprises and non-state-owned listed companies and average are $0.3690,0.36000 .3760$, the proportion of state-owned listed companies and non-listed state-owned enterprises of the largest shareholder, respectively, the minimum and maximum and 0.8523 to 0.0750 and $0.8251,0.0923,14.1195$ and 15.1726, respectively, standard deviation, indicating the proportion of their respective companies for the two samples of the largest shareholder dispersed and distributed a wide gap existed due to the dominance phenomenon.

\section{4 correlation test}

The main variables were state-owned enterprises and non-listed state-owned enterprises listed on two samples were correlation analysis, the test results are shown in Table 4 and Table 5. 
Table 4 state-owned enterprises listed on the variable correlation analysis

\begin{tabular}{|l|l|l|l|l|l|l|l|l|}
\hline variable & roa & age & gend & degre & time & size & lev & topl \\
\hline roa & 1.0000 & & & & & & & \\
\hline age & $0.2728^{* * *}$ & 1.0000 & & & & & & \\
\hline gend & -0.0028 & -0.0507 & 1.0000 & & & & & \\
\hline degre & -0.1042 & $-0.3093^{* * *}$ & -0.0061 & 1.0000 & & & & \\
\hline time & $0.1591^{* *}$ & $0.3501^{* * *}$ & 0.0790 & $-0.1536^{* *}$ & 1.0000 & & & \\
\hline pro & 0.0551 & $0.1318^{*}$ & -0.0725 & $0.2664^{* * *}$ & -0.0139 & 1.0000 & & \\
\hline tak & $-0.4446^{* * *}$ & -0.0912 & -0.0632 & $0.2267^{* * *}$ & 0.0117 & $0.3745^{* * *}$ & 1.0000 & \\
\hline topl & 0.0483 & 0.0338 & 0.0508 & $0.1561^{* *}$ & 0.0055 & $0.2154^{* * *}$ & 0.0515 & 0.0000 \\
\hline
\end{tabular}

Note: *, ** and **** represent tested in $10 \%, 5 \%$ and $1 \%$ level of significance.

Table 5 Non-state-owned enterprises listed variables correlation analysis

\begin{tabular}{|l|l|l|l|l|l|l|l|l|}
\hline variable & roa & age & gend & degre & time & size & lev & topl \\
\hline roa & 1.0000 & & & & & & & \\
\hline age & -0.0624 & 1.0000 & & & & & & \\
\hline gend & -0.0071 & -0.0508 & 1.0000 & & & & & \\
\hline degre & $0.1480^{* *}$ & $-0.1417^{* *}$ & 0.0399 & 1.0000 & & & & \\
\hline time & $0.1246^{* *}$ & $0.1208^{* *}$ & -0.0588 & $0.1018^{*}$ & 1.0000 & & & \\
\hline pro & 0.0825 & 0.0344 & 0.0803 & $0.1355^{* *}$ & 0.0351 & 1.0000 & & \\
\hline tak & $-0.3956^{* * *}$ & 0.0246 & 0.0881 & 0.0471 & 0.0050 & $0.3378^{* * *}$ & 1.0000 & \\
\hline topl & $0.1490^{* *}$ & 0.0456 & -0.0345 & -0.0327 & $-0.1504^{* *}$ & $0.1933^{* * *}$ & -0.0559 & 1.0000 \\
\hline
\end{tabular}

Note: $*{ }^{* *}$ and $* * * *$ represent tested in $10 \%, 5 \%$ and $1 \%$ level of significance.

By Pearson correlation test can be found in the state-owned listed companies in the sample, the manager of age, tenure, management and corporate earnings were significantly correlated with the growth of age, managers, term, help improve corporate earnings management; in non-state-owned listed companies, managers qualifications, tenure, management and enterprise surplus significant correlation between the degree managers, remuneration and the proportion of companies the largest shareholder and corporate earnings management significantly positive correlation between the manager and the term of office corporate earnings management was significantly negatively correlated.

\section{4 recommendations for improving earnings management}

It should be from the management features to control aspects of the management of the earnings management behavior.

First, to increase the proportion of women in senior management team executives. Studies have shown that the proportion of male executives, the higher the earnings management 
company. Chinese listed companies should increase the proportion of female members of the executive team, gender system more rational, the most powerful executives in order to achieve suppression of earnings management.

Second, to improve the overall quality and capacity of the executive team members. The results showed that the executive education level and earnings management how negative correlation. The company should improve the overall quality and ability level executive members, the selection of high education level executives and senior executives to guide the training and learning through professional management knowledge and learning, which will be better theory into practice, to inhibit target earnings management and, ultimately, to ensure that the company's operating results toward a better direction.

Third, pay attention to optimize the composition of the executive team's age, increased attention to older managers. Studies have shown that a company member of the senior management team of the average age of a larger surplus on the lower level management. We should optimize the age structure of the executive team, and to focus on recommendations older managers, an appropriate increase in the number of older managers to effectively suppress earnings management behavior.

Fourth, due to increase executive term limits. This study shows that the executive team working longer, more effective in reducing earnings management behavior. But with the increase executives serving time, will enhance their knowledge and understanding within the team to improve the company's performance and reduce the degree of earnings management. But everything has a limit, if you exceed this limit, it can backfire. So, we should be combined with the actual situation of listed companies, executives set the appropriate term of office.

\section{References:}

1. J. $\mathrm{Lu}$, Chinese Loss Listed Companies' Earnings Management Empirical Research M. Beijing: China Financial and Economic Publishing House, 2002

2. L. Quan. Empirical study of asset impairment policy of listed companies J. China Accounting and Finance Review, 2001.

3. X.Shuang, L. Tian,An Empirical Study of Accounting item accrued and Earnings Management J. Shanghai Lixin University, 2006,3.

4. C. Zhao,Impairment of assets and earnings management analysis J. Accounting Research, 2006,3.

5. Z. Rui, L. Bin, D. Liu, Earnings management of research activities manipulation -empirical evidence-based insurance profit motive J. Mathematical Statistics and Management, 2008,5. 